\title{
MANAGEMENT OF ENDOCRINE DISEASE Congenital adrenal hyperplasia due to 21-hydroxylase deficiency: update on the management of adult patients and prenatal treatment
}

\author{
Anne Bachelot ${ }^{1,2}$, Virginie Grouthier ${ }^{1,2}$, Carine Courtillot ${ }^{1}$, Jérôme Dulon ${ }^{1}$ and \\ Philippe Touraine ${ }^{1,2}$
}

${ }^{1}$ AP-HP, IE3M, Hôpital Pitié-Salpêtrière, Department of Endocrinology and Reproductive Medicine and Centre de Référence des Maladies Endocriniennes Rares de la Croissance, Centre de Référence des Pathologies Gynécologiques Rares, ICAN, Paris, France and ${ }^{2}$ UPMC Université Pierre et Marie Curie, Univ Paris 06, Paris, France
Correspondence should be addressed to $P$ Touraine

Email

philippe.touraine@aphp.fr

\begin{abstract}
Congenital adrenal hyperplasia (CAH) due to 21-hydroxylase deficiency is characterized by cortisol and in some cases aldosterone deficiency associated with androgen excess. Goals of treatment are to replace deficient hormones and control androgen excess, while avoiding the adverse effects of exogenous glucocorticoid. Over the last 5 years, cohorts of adults with CAH due to 21-hydroxylase deficiency from Europe and the United States have been described, allowing us to have a better knowledge of long-term complications of the disease and its treatment. Patients with CAH have increased mortality, morbidity and risk for infertility and metabolic disorders. These comorbidities are due in part to the drawbacks of the currently available glucocorticoid therapy. Consequently, novel therapies are being developed and studied in an attempt to improve patient outcomes. New management strategies in the care of pregnancies at risk for congenital adrenal hyperplasia using fetal sex determination and dexamethasone have also been described, but remain a subject of debate. We focused the present overview on the data published in the last 5 years, concentrating on studies dealing with cardiovascular risk, fertility, treatment and prenatal management in adults with classic $\mathrm{CAH}$ to provide the reader with an updated review on this rapidly evolving field of knowledge.
\end{abstract}

Invited author's profile

Philippe Touraine MD, PhD, is the Head of the Department of Endocrinology and Reproductive Medicine at the Hôpitaux Universitaires Pitié Salpêtrière-Charles Foix, Paris, France and a full professor at ParisVI, Université Pierre et Marie Curie, Paris. He is the leader of two groups dedicated to rare endocrine and gynecological disorders. He also leads one of the groups belonging to the European Rare Network on Sex Differentiation Disorders. His major research interests include the pathogenesis and treatment of pituitary tumors, the role of prolactin in human breast diseases, the pathogenesis and the genetics of premature ovarian failure, the management of patients with congenital adrenal hyperplasia during transition and adulthood and finally the treatment of growth hormone deficiency in adults.

(ㄷ) 2017 European Society of Endocrinology Printed in Great Britain

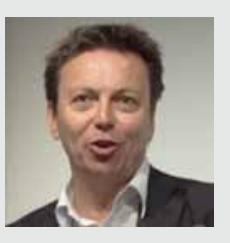




\section{Introduction}

Congenital adrenal hyperplasia (CAH, MIM 201910) corresponds to a group of inherited autosomal recessive disorders that arise from defective steroidogenesis and results from a deficiency in one or several of the enzymes of cortisol biosynthesis.

Deficiency of the 21-hydroxylase enzyme is the most common form of $\mathrm{CAH}$, accounting for more than 95\% of the cases and is one of the most commonly known autosomal recessive disorders. CAH due to 21-hydroxylase deficiency (21OHD) is the result of deletions or deleterious mutations in the active gene CYP21A2 (1). There are many mutations of the CYP21A2 gene identified so far, which are the causes of varying degrees of impairment of 21-hydroxylase activity (2). Most patients are compound heterozygotes. The clinical phenotype, related to the less-severe mutated allele, is classified as classic for the severe form, or non-classic (NC). Classic CAH encompasses salt-wasting (SW) or simple virilizing (SV) forms, depending on the degree of aldosterone deficiency. Hormonal treatment is based on cortisol and, when necessary, aldosterone substitution. Its role is to reduce the excessive ACTH production and consequently the increased androgen production by the adrenal gland, to ensure normal fertility, and to avoid the long-term consequences of glucocorticoid (GC) use. The physiological circadian rhythm of cortisol cannot be mimicked with oral GC, and the doses needed to suppress the androgens are usually higher than those needed for substitution $(1,2,3)$.

In this review, we decided to focus on the new findings published on $\mathrm{CAH}$ over the last 5 years. An exhaustive PubMed research has been performed with the terms 'congenital adrenal hyperplasia' and '21-hydroxylase deficiency'. For space constraints, we excluded all the data that were dealing with non-classic $\mathrm{CAH}$ and childhood outcomes of $\mathrm{CAH}$, to focus on studies dealing with classic $\mathrm{CAH}$ in adults or prenatal management. We also chose to go further into four themes: cardiovascular risk, fertility, treatment and prenatal management as most of the recent publications concern those topics.

\section{Cardiovascular (CV) risk}

Cohorts of adults with CAH due to 21OHD from Europe $(4,5,6)$ and the United States (7) have been described in the recent years. They have shown an increased risk for metabolic disorders in adults $(1,3,8,9)$. Overweight and obesity have been reported in adult patients with CAH. In the prospective cross-sectional study conducted in the United Kingdom (UK) among 199 patients, BMI was found to be higher in CAH patients than that in the general population of the Health Survey for England data (4). In the American cross-sectional study of $244 \mathrm{CAH}$ patients, prevalence of obesity (one-third of patients across phenotypes) was similar to the adult U.S. obesity rate of $36 \%$ (7). In two French cohorts of respectively 108 and 219 patients, the prevalence of obesity and overweight in $\mathrm{CAH}$ patients was similar to that found in the general population in the latest nationwide survey $(5,10)$. More recently, repartition of adipose tissue was precisely studied in $\mathrm{CAH}$ adolescents and young adults (11). Increased abdominal adiposity, with a higher proportion of proinflammatory visceral adipose tissue compared to subcutaneous adipose tissue was present in CAH patients compared to age-, sex- and BMI-matched controls. Metabolic syndrome was also evaluated in $\mathrm{CAH}$ patients and was observed in nearly $20 \%$ of adults in the $\mathrm{NIH}$ cohort (7). It was associated with older age, whereas no association was found with androgens, GC type or dose (7). In a Brazilian cohort of young $\mathrm{CAH}$ patients, there was a higher prevalence of metabolic syndrome, which was associated to family history of metabolic syndrome (12). As these studies were cross-sectional, it would be interesting to follow-up the patients longitudinally to perform an association analysis of glucocorticoid, androgen exposure, BMI and visceral fat.

Blood pressure (BP) control in children and adult $\mathrm{CAH}$ patients has been investigated by several independent groups, with some studies reporting normal resting $(13,14,15,16)$ and 24-hour BP profile (17) and others reporting a slight increase of either diurnal or both diurnal and nocturnal SBP, compared to matched controls $(4,18,19,20,21,22,23)$. These differences may be influenced by the methods for recording blood pressure. There are minimal data available on the prevalence of hypertension in adult patients with $\mathrm{CAH}$ (24). In a recent epidemiological Swedish registry study, increased frequency of hypertension in individuals with CAH has been shown, but when analyzing the different subgroups, only SV females had increased blood pressure, whereas this was rare or nonexistent in the more severe phenotypes and genotypes (6). This was in accordance with a recent study showing that adult males with classic $\mathrm{CAH}$ have a rather low BP compared with healthy men (10). Dyslipidemia in individuals with CAH has been 
reported in some studies. In the epidemiological Swedish registry study, an increased rate of dyslipidemia was found, especially in males with a null genotype (6). In the NIH cohort, approximately $10 \%$ of both classic and NC adult patients had decreased HDL. In adults, $6 \%$ had elevated total cholesterol, whereas approximately 15\% had decreased HDL (7).

In this intricate scenario, it is reasonable to expect a high CV risk profile in CAH patients. However, the impact of these risk factors on the vascular system has never been systematically ascertained. Cardiovascular morbidity and mortality are not easy to bring out in this population, as very few of the studied patients are aged older than 50 years. Carotid intima-media thickness (cIMT) is a well-established marker of early, subclinical atherosclerotic change, that is correlated to the risk for coronary artery disease and stroke (25). However, cIMT results vary in existing studies of individuals with $\mathrm{CAH}$ $(12,14,26,27,28,29)$. Adults with $\mathrm{CAH}$ have been found to have increased cIMT in one study (15). There was no correlation between cIMT and cumulative GC doses or androgen levels. Further studies in children or adolescent CAH patients showed normal cIMT compared to a BMI-matched cohort $(12,26)$ or increased cIMT compared to controls, but found it linked to higher BMI and unfavorable metabolic parameters $(27,28,29)$. These variations between studies may be due to differences in measures and in study design. Other surrogate markers of endothelial or cardiac dysfunction have been studied. Children with CAH have been shown to have significant vascular endothelial and smooth muscle dysfunctions, at a level comparable to the subjects with mild-to-moderate obesity (12). In adolescent and adult CAH patients, normal left ventricular morphology has been reported $(13,16)$, but mild diastolic dysfunction and impaired exercise performance were shown. Recently, we reported the complex interactions between gonadotropins and steroid hormones on the duration of ventricular repolarization. We found that CAH QT interval duration was shorter in women with CAH than that in control women (30). These findings and their clinical impact have to be further examined. The association between endothelial dysfunction, cIMT progression, hormonal imbalance, treatment of $\mathrm{CAH}$ and $\mathrm{CV}$ events, will be important to figure out in this at-risk cohort.

The rate of $\mathrm{CV}$ events among adults with $\mathrm{CAH}$ is beginning to be characterized (6). The long-term outcomes in $\mathrm{CAH}$ patients were studied using the Swedish national
CAH registry. Five hundred eighty-eight patients (335 females and 253 males) were compared with 100 controls per patient, matched for sex, year and place of birth (31). Information on mortality, cause of death, morbidity and mortality was derived through linkage of national population-based registers. The mean age of death was lower in CAH patients $(41.2 \pm 26.9$ vs $47.7 \pm 27.7$ years $(P<0.001))$. The hazard ratio of death was $2.3(1.2-4.3)$ in males and 3.5 (2.0-6.0) in females. The causes of death were adrenal crisis (42\%), cardiovascular diseases (32\%), cancer $(16 \%)$ and suicide (10\%).

Interestingly, the same team analyzed $\mathrm{CV}$ and metabolic morbidity in CAH patients (6). This study showed an increase in both $\mathrm{CV}$ and metabolic disorders (OR (odds ratio): 3.9; 95\% CI (confidence interval): 3.15.0) and CV disease (OR: 2.7; 95\% CI: 1.9-3.9), with some subgroups being more affected than others (females, specifically I172N and NC and males in the null genotype group). Separate analyses of the individual diseases showed higher frequencies of hypertension, dyslipidemia and atrial fibrillation in CAH patients (6). Obesity was consistently increased in all subgroups. However, the nonobese patients with CAH were similarly affected as the entire CAH cohort. There was also an increased frequency of obstructive sleep apnea in this CAH cohort. Similarly, the frequency of diabetes was increased, especially in females with SV (I172N genotype) or NC phenotype. Increased frequency of venous thromboembolic events was also reported. This should be further studied to determine if, as reported in both Cushing's syndrome and GC use, there is a higher risk of venous thromboembolism due to a state of hypercoagulability that should lead to more frequent use of thrombosis prophylaxis in this population.

$\mathrm{CAH}$ is therefore associated with higher $\mathrm{CV}$ risk factors and probably with excess $\mathrm{CV}$ and metabolic morbidity. Some subgroups of patients seem to be more affected. Regular follow-up is needed, along with lifestyle interventions, to limit the onset of weight gain and obesity, to screen for diabetes, other metabolic disorders and CV risk factors. Close monitoring of GC doses is important. Further studies on larger cohorts are necessary to better clarify the mechanisms leading to metabolic and $\mathrm{CV}$ abnormalities and to precise the respective roles of androgen and lifelong GC treatment, as well as the impact of new findings, such as GC receptor gene polymorphisms, which have recently been shown to be associated with an adverse metabolic profile (32). 


\section{Female fertility}

Fertility in women with classic CAH is reduced, especially for the patients with the SW form, as a result of several issues such as biological (poor hormonal balance), mechanical (related to surgeries), psychological and sexual factors $(33,34)$.

Menstrual irregularities and anovulation are frequent in $\mathrm{CAH}$ women, affecting from $30 \%$ to $68 \%$ of women with the SW form and $30-75 \%$ of those with the SV form (4). Menstrual cycle control represents therefore an important therapeutic target in these patients. Several factors (androgen and progesterone overproduction and prenatal exposure to sexual steroid) are suspected to disturb the reproductive axis in $\mathrm{CAH}$ females. A recent study has described LH pulsatility in women with classic CAH (35). No differences have been observed between patients and controls in terms of mean LH levels, LH pulse amplitude or LH frequency. In CAH patients, 2 different profiles of LH pulsatility were recorded. One group of patients had LH pulsatility patterns similar to the controls. The other one had lower LH pulses amplitude and frequency and presented more frequently with menstrual cycle disturbances, higher $17 \mathrm{OH}$ progesterone (17OHP), testosterone, progesterone and androstenedione levels and lower FSH levels. This study has suggested the absence of a neonatal programming of a disrupted gonadotropic axis and has shown that $\mathrm{CAH}$ adult women may have a normal LH pulsatility and secretion and that hormonal control is a key factor. Optimized GC and mineralocorticoid (MC) regimens during fertility monitoring should thus be an important concern in CAH women, and in particular, suppression of serum progesterone concentrations, that are probably responsible for reduced LH pulsatility during the follicular phase of the menstrual cycle.

The consequences of the genital surgery are another factor implicated in the reduced fertility of $\mathrm{CAH}$ women. Surgery can include clitoroplasty, vaginoplasty and labiaplasty (36). Thanks to a detailed assessment of current surgery practice, during a limited period of 4 -years, a recent American study has shown that the feminizing genitoplasty in infants with CAH continues to be performed and that approximately in $90 \%$ of the case it includes a vaginoplasty as a portion of the procedure (37). It was also found that combined vaginoplasty and clitoroplasty is the most common procedure performed in infancy and early childhood and appears to be primarily restricted to this age range despite controversy regarding the optimal timing of vaginoplasty. Second and third procedures were performed later in childhood or adolescence and about 2/3 were performed by experimented surgeons. Urinary incontinence, vaginal stenosis and inadequate introitus, poor cosmetics, anorgasmia and painful intercourse have been reported and currently remain relevant issues $(36,38)$. It is well established that there is a relationship between sexual activity and vaginal function; thus, genital surgery may result in sexual dissatisfaction. Surgical techniques for genital feminization in female $\mathrm{CAH}$ patients have evolved significantly over time. There are nowadays new surgical procedures that, for instance, preserve innervation and clitoral sensation to conserve erotic sensitivity and orgasmic capacity secondary to the clitoroplasty (39) and improved vaginoplasty techniques (40). Moreover, to date, the choice of the timing of the surgery (early or late surgery) remains therefore a matter of debate (41). Unfortunately, there are few data in the literature about the outcomes of this surgery in terms of sexual function, and the outcomes of the current techniques will take time to emerge. In a cohort study of $138 \mathrm{CAH}$ patients, Arlt et al. have shown that 92 women had undergone genital reconstruction, $43 \%$ of whom had more than one surgery and $23 \%$ during adulthood (4). Among these patients, $46 \%$ have stated being unhappy about their sexual life. In a more recent review including 151 patients with genitoplasty, assessments of cosmetic results have shown that the majority of patients (between 60 and 94\%) reported good or excellent outcomes (36). When the physician was the person who assessed the cosmetic outcomes, 59-94\% reported satisfactory results (36).

Fertility rate, i.e. live births per woman, is significantly lower in $\mathrm{CAH}$ women than in the general female population (42). On the other hand, pregnancy estimates are more encouraging when examined only in the patients actively trying to conceive (43). In a UK cohort of $103 \mathrm{CAH}$ women among whom $25 \%$ wanted to conceive, the pregnancy estimate was 54\% (4). Pregnancies were most often spontaneous, obtained after a good hormonal control with optimized GC and MC regimens. Recently, a large population-based epidemiological study on psychosocial outcomes in $\mathrm{CAH}$ patients was conducted in Sweden. Five hundred and eighty-eight CAH patients including 253 women were compared to the general population (44). Women with the SW form were less often married (OR: 0.5 (0.2-1.1)) and had fewer partnerships compared with controls. CAH patients were less likely to have biological children than controls (OR: $0.3(0.2-0.3)$ ) and when assessing women with the SW and SV forms, 
it was still significantly decreased (SW OR: $0.05(0.0-0.1)$; SV OR: 0.4 (0.2-0.7)). Better fertility and fecundity in CAH women will be largely dependent on surgical advances in genital reconstruction, earlier treatment, optimized compliance to therapy, availability of psychological support, organization of transition from pediatric to adult specialist care, procuration of menstrual cycle control and sexual well-being.

\section{Male fertility}

Male patients with CAH may present impaired gonadic function and infertility. It appears that adult males with $\mathrm{CAH}$ face a dual problem. Adrenal steroid overproduction, especially androgen and progesterone, might interfere with FSH and LH production, resulting in gonadotropic deficiency. In addition, testicular adrenal rest tumors (TARTs) may become hypertrophic under chronic ACTH stimulation and influence both endocrine and exocrine testicular functions (45). TARTs have been identified with a prevalence of 30-95\% depending on age and modality of diagnosis, i.e. palpation or ultrasound $(10,46)$. The prevalence of TARTs increases with age, after onset of puberty $(47,48)$. TARTs volume and prevalence seem higher in patients with SW form compared with those in the SV form $(46,49,50)$. Some studies report the development of TARTs despite good hormonal control, suggesting that undertreatment is not the only cause for their growth $(51,52)$. Indeed, a recent study about molecular characterization of TARTs has shown that these tumors have multiple steroidogenic properties, including the expression of adrenal cortex and typical Leydig cell markers (53).

TARTs are most often responsible for impaired spermatogenesis. In patients with and without TARTs, inhibin B levels differ significantly and there are higher total sperm counts and concentration in patients without TARTs (10). In a large cohort of 164 male CAH patients who underwent testicular assessment with ultrasound, 71 had a sperm analysis. Seventy percent of the patients had severe oligospermia or azoospermia when TARTs were found versus only $3.6 \%$ when they were not (10). Because of their central localization near the rete testis, TARTs can lead to compression of the seminiferous tubules that may finally lead to obstructive azoospermia and irreversible damage of the surrounding testicular tissue (49). They also can destroy and replace healthy testicular tissue. The profile of the gonadotropic-testicular axis in these patients will primarily show testicular failure and eventually reveal endocrine and exocrine testicular dysfunctions (54).

Treatment options for male patients with TARTs are still limited and mainly based on a good hormonal control with GC (50). However, in some patients, treatment is poorly tolerated, and the medical response is disappointing. Surgery can be proposed but there are no data on fertility preservation. Recently, Bry-Gaillard et al. have shown that mitotane could restore fertility in $\mathrm{CAH}$ patients with TARTs (54). After 8 months of treatment, gonadotropins levels, inhibin B and sperm counts have improved, and on the other hand, size of TARTs has shrunk. Prevention has a real important place in the management of male CAH fertility. A systematic ultrasound evaluation is recommended at puberty to detect lesions at an early stage. A semen analysis should also be realized as soon as possible, and the question of systematic sperm cryopreservation seems fully justified (55).

Reduced fertility in CAH men can also be secondary to hypogonadotropic hypogonadism due to poor hormonal control with increased adrenal androgens and progesterone, leading to an increase in estrogen levels by aromatization. A recent case report has demonstrated the restoration of fertility by gonadotropin replacement in a CAH man (56). The patient had hypogonadotropic azoospermia and TARTs due to untreated SV form. A treatment with gonadotropin replacement permitted to obtain after 21 months a stable low sperm concentration with good sperm motility, enabling the couple to have a healthy girl.

Besides these somatic causes of impaired fertility in $\mathrm{CAH}$ males, there might be aspects of psychosocial adaptation and sexual well-being. Very few data have been reported on sexual satisfaction in CAH males. Two recent studies have shown that fewer $\mathrm{CAH}$ patients than controls had an active sexual life and that they had fewer lifetime partners $(57,58)$. In a Swedish cohort of $30 \mathrm{CAH}$ males, erectile dysfunction was found in about half of these patients (58) as was described in the study from Dudzinska et al. (59). A sexual well-being study of $20 \mathrm{CAH}$ males has revealed impairments in sexual drive, erections and ejaculations (59). Poor control disease was associated with a reduced sexual drive. However, in the recent Swedish follow-up study described previously, although the reason is unknown, men were more often married than controls (OR $1.6(1.0-2.5)$ ) but, as the CAH women, they had less biological children than controls (OR 0.4 $(0.2-0.6))$ (44). Further studies are needed to properly assess these psychosocial outcomes, to improve the care given to the patients. 


\section{Treatment of classic CAH in adults}

Treatment in classic $21 \mathrm{OHD}$ is necessary to compensate for GC and MC deficiencies and also to correct adrenal androgen excess. Ideally, the treatment should be monitored to avoid iatrogenic comorbidities and to enable a good quality of life (60). However, this goal is not reached up to now as increased comorbidities and mortality are reported in patients with $\mathrm{CAH}$.

GC substitution is available since the 50s. Although this treatment has notably changed the prognosis of children with $\mathrm{CAH}$, it has remained the only medical solution for the last decades and has failed to meet all the needs for the patient. Indeed, contrarily to primary adrenal insufficiency, the aim of GC treatment is not only to compensate for the deficient hormone but also to blunt the nocturnal ACTH secretion, which is the major driver of adrenal androgen production. As cortisol is secreted mainly in the morning and, reaches a peak between 06:00 and 08:00 h, most oral GC regimens are proposed with at least half or $2 / 3$ of the global dose in the morning. Up until now, whatever regimen was used, the

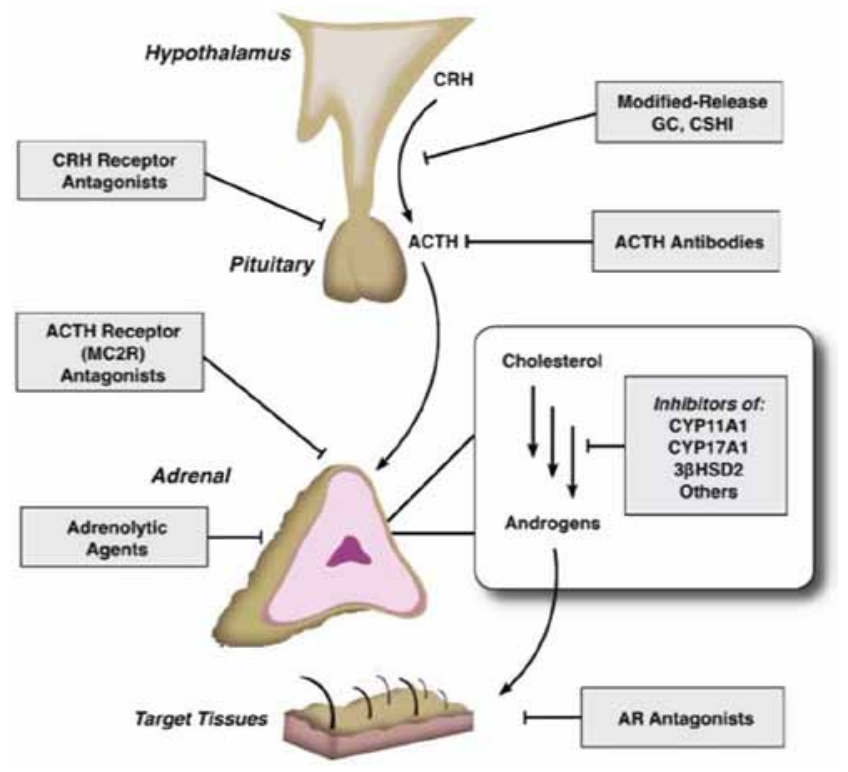

Figure 1

Potential therapeutic targets in congenital adrenal hyperplasia. 3 $\beta \mathrm{HSD} 2$, 3-hydroxysteroid dehydrogenase type 2; $\mathrm{ACTH}$, adrenocorticotropin hormone; $\mathrm{AR}$, androgen receptor; $\mathrm{CRH}$, corticotropin-releasing hormone; $\mathrm{CSHI}$, continuous subcutaneous hydrocortisone infusion; CYP11A1, cholesterol side chain cleavage enzyme; CYP17A1, 17 $\alpha$ hydroxylase/17,20 lyase; GC, glucocorticoids. dilemma has persisted between using the physiological hydrocortisone (HC), well tolerated but with a poor control of androgen secretion or the long-acting prednisone, prednisolone or dexamethasone (DEX), with a higher risk of side effects. Unfortunately, an adequate androgen secretion is difficult to achieve without a high dose of GC, therefore leading to side effects in relation to hypercorticism. Recently, a new slow-release $\mathrm{HC}$ formula (Plenadren) has become available and another one (Chronocort) is currently under investigation. In addition, besides the GC approach, non-GC approaches are under current development, such as the use of molecules interfering with $\mathrm{CRH}$ function and nonselective adrenal steroidogenesis blockade (61) (Fig. 1).

\section{New glucocorticoid approaches}

\section{Treatment of classic CAH adults}

The first molecule is a dual-release HC, which was developed for once-daily morning administration in patients with primary adrenal insufficiency (Plenadren ${ }^{(\mathrm{R})}$, ViroPharma-Shire) (62). It is a modified-release HC with an outer coating layer that provides an immediate release of the drug and an extended-release core. It provides a more extended serum profile of cortisol compared with immediate-release HC. In adults, a single morning dose of Plenadren gives similar cortisol exposure to a thricedaily regimen of immediate-release HC. Preliminary studies in patients with primary adrenal insufficiency and $\mathrm{CAH}$ have demonstrated that this new formula compared with HC regimen, improves body weight, systolic and diastolic blood pressure and glucose metabolism $(63,64)$. This molecule also provides a more circadianbased serum cortisol profile in patients with primary adrenal insufficiency. Unfortunately, there are no data currently available regarding hormonal control in patients with CAH. However, in the latter case, this molecule is unlikely to control excess androgens as the overnight rise in cortisol is not replicated, and evening administration of Plenadren would expose patients to high levels of cortisol during the night.

The second molecule, Chronocort ${ }^{(\mathrm{R})}$, is under current development by Diurnal (Cardiff, UK) (65). This molecule is a modified-release HC, but it differs from Plenadren by having a delayed and sustained absorption profile rather than an immediate- and sustained-release profile. Chronocort aims at replacing physiological cortisol concentrations by dosing at morning and 
night such that the night dose provides release of $\mathrm{HC}$ in the early hours of the morning providing a pre-waking rise in cortisol levels. In a first phase II, openlabel study, Chronocort has shown its ability to decrease the 08:00 h 17OHP level; however, androgen levels rise in the afternoon with once-daily dosing, suggesting that an additional morning dose of GC is needed (66). Another phase 2 study on 16 patients was designed to evaluate the efficiency of a double dose of Chronocort $(10 \mathrm{mg}$ at $07: 00 \mathrm{~h}$ and $20 \mathrm{mg}$ at 23:00 h). It showed that after 6 months of treatment, the mean androstenedione and 17OHP levels were diminished compared with those observed under classical GC therapies (67). These preliminary data need to be confirmed also on clinical parameters and in larger populations.

Before the development of these new molecules, the use of parenteral GC had been discussed. The reproduction of cortisol circadian rhythm permitted to bring 17OHP and ACTH levels closer to physiological values compared to conventional therapies (68). More recently, a continuous subcutaneous HC infusion was found to be more efficient than conventional GC in a randomized trial on 33 patients with primary adrenal insufficiency. Doses of HC were adjusted depending on salivary cortisol. In this study, ACTH levels and cortisol profiles were respectively lower and more physiological than those observed under conventional GC therapy. However, the impact of this treatment on quality of life remains a matter of debate $(69,70)$. Another approach has been proposed to improve the dynamics of $\mathrm{HC}$ infusions. In healthy volunteers, intrinsic adrenal function was blocked by DEX, whereas HC was permanently infused subcutaneously (71). Cortisol and ACTH were measured every 10 and $60 \mathrm{~min}$, leading to the replication of the circadian rhythmicity. A recent phase 2 trial on the use of subcutaneous hydrocortisone pump in $8 \mathrm{CAH}$ patients with poor control has been published (72). In this study, subcutaneous hydrocortisone pump approximated physiologic cortisol secretion. Six-month treatment resulted in improved adrenal steroid control and had positive effects on quality of life. All these studies may be considered as interesting or even more promising; however, they also underline the difficulty in managing the patients daily (71). The cost of these pumps, the potential dysfunction and local irritation, may also be considered as limiting factors. The longterm effect, tolerance and acceptation of this treatment will require further studies.

\section{Non-glucocorticoid approaches}

\section{Treatment of classic CAH adults}

The most radical treatment is the surgical removal of both adrenal glands. This approach must be carefully discussed as it can induce the development of TARTs in men and less frequently retroperitoneal adrenal rest tumors in women $(73,74)$. Chemical adrenalectomy may be obtained using mitotane, an adrenolytic agent for which the mechanisms of action remain poorly understood. Recent evidence focuses on apoptotic effects at adrenocortical level reducing the activity of the respiratory chain complex and inducing mitochondrial fragmentation, leading to programmed cell death $(75,76)$. Mitotane also modulates the expression of several genes involved in steroid hormone biosynthesis (76). In addition, the lack of LH increase after the decrease in free testosterone suggests that mitotane may have a toxic effect on the testes and also on the pituitary by reducing the viability of gonadotroph cell lines through activated apoptosis (75).

Two novel approaches are under current investigation: the development of androgen biosynthesis inhibitors and the development of ACTH and CRH receptor antagonists.

The development of androgen biosynthesis inhibitors is based on the necessity of decreasing secretion and action of androgens since, as previously mentioned, most of the GC treatments are unable to induce such blockade. Abiraterone is an inhibitor of CYP17A1, an enzyme necessary for androgen synthesis (Fig. 1). In men treated for prostate cancer, abiraterone acetate has proven its efficiency in decreasing testosterone levels (77). A recent phase I study in CAH women permitted to observe, after 6 days of treatment, a decrease by $2 / 3$ of the androstenedione level when the administered dose was $100 \mathrm{mg} /$ day. When the dose was increased up to $250 \mathrm{mg} /$ day the androstenedione level was completely normalized after 6 days of treatment. However, this approach does not compensate for the adrenal insufficiency, and therefore, requires the adjunction of a GC, and in some patients, MC treatment (78). This treatment cannot be used in male patients, as it blocks all androgen synthesis.

As ACTH is a key factor in controlling adrenal function, the opportunity of interfering with corticotroph axis has been proposed. ACTH is the only known naturally occurring agonist for its receptor. The high degree of ligand specificity suggests that antagonism of its receptor could provide a useful therapeutic approach and at least an investigational tool. Different experimental models, in 
animals, may provide new insights in this potential new approach (79).

Besides ACTH, CRH is at the hypothalamic level, the key factor inducing, after a specific binding to CRH receptor type 1, ACTH secretion. Any antagonism to this receptor could be a potential therapeutic strategy. This approach has been recently explored with a selective CRH receptor type 1 antagonist NBI-77860. In a singleblind, placebo-controlled study, 8 patients with $\mathrm{CAH}$ have received a fixed dose of 300 or $600 \mathrm{mg}$, each period of treatment being separated by a 3 weeks washout time; treatment was prescribed at 22:00h, and ACTH and $17 \mathrm{OHP}$ were measured sequentially during the day after treatment administration. There was a reduction of ACTH by a mean of $43 \%$ and $41 \%$, under 300 and $600 \mathrm{mg}$ respectively compared with placebo, whereas $17 \mathrm{OHP}$ was reduced by a mean of $0.7 \%$ and $27 \%$ under the same treatments (80). These promising data provide a rationale for ongoing experimental studies using CRH receptor antagonist, without forgetting that this approach does not compensate for cortisol and aldosterone deficiencies.

\section{Prenatal management of CAH}

In $\mathrm{CAH}, 46 \mathrm{XX}$ female fetuses are virilized in utero due to their increased exposure to androgens. This results in the development of clitoromegaly, fusion of the labioscrotal folds and formation of a common urogenital sinus in place of a separate urethra and vagina. The aim of prenatal treatment is to avoid the need for surgery in the little girl and to relieve the emotional distress and anxiety of the parents that may be caused by an external genitalia anomaly in their child.

Prenatal treatment was first introduced in the early 80 s $(81,82)$, using DEX, which is a synthetic GC with a long half-life, not deactivated by the placental 11-hydroxysteroid dehydrogenase type 2 and that crosses the placenta and becomes bioavailable to the fetus. In the CAH fetus, DEX leads to ACTH suppression and reduction of androgen excess, which blocks the virilization of the external genitalia in female fetuses. The dose of DEX used is $20 \mu \mathrm{g} / \mathrm{kg}$ maternal body weight (pre-conception)/day, divided in 2 or 3 daily doses, without exceeding $1.5 \mathrm{mg} /$ day $(83,84)$. This dose corresponds to about 6 times the physiologic GC needs of the mother $(85,86)$ and 60 times the fetus' $(87,88)$. Studies with lower doses have not been performed, but some data show that the DEX dose could probably be reduced when poorly tolerated in the mother $(89,90)$. DEX must be initiated before the presumed date of genital sensitivity to androgens, at the latest at the 7th week of gestation (WG) or 9th week of amenorrhea and continued until birth in CAH females to ensure its efficacy (91, 92, 93, 94, 95, 96). The timing of DEX initiation seems to play an essential role in the genital morphology of CAH girls $(90,97)$.

Early DEX initiation before $7 \mathrm{WG}$, ideally at the latest at $6 \mathrm{WG}$, and its maintenance during the whole gestation have resulted in normal feminine genitalia in CAH girls in $80-85 \%$ cases, failure being usually observed when treatment was started after 8 WG $(84,90,92,93,94$, 95, 98). A recent small study from French surgeons has suggested that prenatal DEX therapy could potentially be limited to the period of the partitioning window, during the time of urogenital cleavage, which would both reduce total fetal exposure to DEX, yet still facilitate easier surgical correction (99). Enlargement of the genital tubercle continues to occur in late pregnancy without ongoing antenatal treatment, but it is generally responsive to postnatal treatment $(100,101)$.

Prenatal DEX exposure has decreased over the years. Circulating cell-free DNA in maternal serum allows fetal sex determination by detecting the Y chromosome (SRY test). It was first described in the late 90s (102) and used in CAH a few years later to prevent the use of DEX in $\mathrm{CAH}$ males and to initiate the treatment at the latest at 6 WG in females $(103,104)$. It has recently been shown that the sensitivity of the SRY test was guaranteed just after 4 WG in 96\% cases (90). Moreover, trophoblast retrieval and isolation from the cervix was recently proven to be an approach that noninvasively and correctly identifies male fetal DNA in fetuses at risk for CAH as early as 5 WG (105). In addition, the development of chorionic villi sampling (CVS) performed earlier than amniocentesis (approximately 14 WG vs $20 \mathrm{WG}$ ) and with a shorter response delay has allowed minimizing DEX exposure of non-CAH females. Very interestingly, the first demonstration of non-invasive prenatal diagnosis of $\mathrm{CAH}$ using cell-free fetal DNA in maternal plasma, as early as 6 WG, has recently been published $(106,107)$. Even though large-scale prospective studies are needed, this technique offers the possibility to only treat the affected female fetus.

Prenatal DEX, however, continues to be a subject of debate. Rare adverse events have been reported in treated children, but no harmful effects have been documented that can be clearly attributed to this treatment $(84,108)$. A large study on $600 \mathrm{CAH}$-affected pregnancies where infants were treated prenatally with DEX, reported no significant difference in head circumference, birth weight or length, compared to untreated affected siblings (109). A long-term follow-up study in Scandinavia showed 
that 44 children who were variably treated prenatally demonstrated normal prenatal and postnatal growth compared to matched controls. Furthermore, there was no observed increase in fetal abnormalities or fetal death (95). A recent large French retrospective study confirmed the absence of malformations and of growth restriction at birth (90). Maternal side effects of prenatal DEX include weight gain, edema, mood change, sleep disturbance, acne and striae $(84,98,109)$. However, there has not been a confirmed association with major pregnancy complications such as hypertension, gestational diabetes, stillbirth or spontaneous abortions $(98,109)$. It has recently been shown that nanoencapsulation of DEX enhances the permeability of the drug from the maternal to the fetal compartment more than 10-fold, allowing the delivery of the medication to the fetus while minimizing the adverse effects in the mother (110).

Concerns have been raised in regard to the GC effects on the fetal brain, which arise from studies of other conditions rather than direct studies on prenatal treatment of $\mathrm{CAH}$. These include studies where much higher doses were given to the human subjects at the later part of pregnancy or to animals $(111,112,113,114)$, potentially holding little relevance to prenatal DEX in CAH. A small study M. New's group described children prenatally exposed to DEX compared to untreated children from CAH at-risk pregnancies and showed no significant differences in cognitive abilities but demonstrated an increase in internalizing behaviors, such as being more shy, more emotional and less sociable (115). Another large study from the same group was unable to find any adverse effects of prenatal DEX on motor and cognitive outcome (116). Recently, the same American group published a large study evaluating the long-term effects of prenatal DEX in affected and unaffected CAH patients and found no adverse effects such as increased risk for cognitive defects, disorders of gender identity and behavior or sexual function in adulthood (117). Conversely, in a small-sample Swedish study of 26 children treated with DEX in utero, compared to 35 matched controls, the authors from S. Lajic's group found no effects on intelligence, handedness, memory encoding or longterm memory. However, they found that, in comparison to controls, CAH-unaffected children treated prenatally for a short time had significantly poorer performance on a test of verbal working memory. In addition, treated children had lower questionnaire scores than controls in self-perceived social anxiety and scholastic competence (118). On the other hand, parents described their treated children as more sociable than the controls' parents
Table 1 Management of adult patients with classic $\mathrm{CAH}$.

Monitoring of the efficacy of glucocorticoid replacement therapy

Early-morning serum concentrations of 17-OHP $\triangle 4$-androstenedione, total testosterone, SHBG approximately every six to 12 months Diurnal 170HP curve with dried blood spots if available Weight gain and clinical signs of cortisol and androgen excess

Monitoring of the efficacy of mineralocorticoid replacement Blood pressure Plasma electrolytes

Early-morning plasma renin activity concentration

Periodic measurements and/or monitoring of the following: Weight

Lipid profile

Blood pressure

Glycemia

Bone mineral density

Assessment of male gonadic function and fertility

Testicular adrenal rest by ultrasonography

Sperm analysis

Fertility preservation

Hormonal measurements: total testosterone, LH, FSH

Assessment of female gonadic function and fertility Gynecological, obstetrical and endocrinological care Menstrual cycle

Sexuality

Clinical and biological hyperandrogenism

Hormonal measurements: progesterone, estradiol, FSH

Genetic counseling

Pregnancy management

Close monitorage by a gynecologist and an endocrinologist Psychological support

did, and treated children did not display any significant difference in psychopathology, school performance, adaptive functioning or behavioral fields (119). In the same patients, the authors suggest effects on gender role behavior in boys exposed to short-term prenatal DEX (120). A large neuropsychological American study also found that subjects treated with short-term prenatal DEX actually performed better than controls in most areas of mental processing and memory performance; however, girls treated with DEX in the long-term had slower mental processing (117).

Despite these inconsistencies, a meta-analysis has found no significant difference in neuropsychological outcomes of children treated prenatally with DEX, although only 4 eligible observational studies were identified, which in addition had low methodological quality (98). Moreover, a very recent Scandinavian study concluded that non-CAH children who were treated with DEX during early fetal life seemed to be well adjusted without major behavioral or emotional problems, as assessed by their parents, and even scored lower than the 
control subjects on items assessing anxiety in new, social situations (121).

Since the early 2000, several medical societies have issued opinions concerning prenatal treatment of $\mathrm{CAH}$ based on data presented previously and agreed that it is experimental and should only be done in Institutional Review Board-approved prospective research protocols, with written informed consent, and that this treatment is inappropriate for use in community practice (122, $123,124,125,126,127)$. The Swedish group has stopped recruiting patients due to concerns regarding abnormal behavioral development in children exposed to prenatal DEX and notified the Regional Ethics Committee in Stockholm (128).

It is certain that DEX safety in children treated in utero remains controversial and needs to be better assessed. However, the review of the literature shows an overall efficacy of prenatal DEX. The actual perspective of only treating affected girls with specific transplacental delivery devices, even though the techniques are not routine yet, is a major improvement in the care of these at-risk pregnancies. It is obvious that treatment should only be proposed in multidisciplinary reference centers, with informed consent of the parents and long-term follow-up of the prenatally treated patients.

\section{Conclusion}

Recent years have brought new insights in the description of CAH comorbidities especially in the CV and fertility areas (Table 1). In both cases, this description suggests the need for new therapeutic approaches. After decades of relatively stagnant progress, advances are now noted. Besides improved GC delivery systems, oral or parenteral, new GC approaches are under current elevation such as inhibitors of androgen biosynthetic enzymes or CRH receptor antagonists. All these approaches may have pros and cons. In all cases, larger trials to determine the outcomes and safety profiles are needed, in adults as well as in children. The use of DEX during pregnancy remains another matter of debate. Its use to prevent or diminish the risk of virilization of the young girl has to be discussed taking account the potential long-term use of such molecules on brain function or metabolism.

\section{References}

1 Auchus RJ. The classic and nonclassic concenital adrenal hyperplasias. Endocrine Practice 201521 383-389. (doi:10.4158/ EP14474)
2 New MI, Abraham M, Gonzalez B, Dumic M, Razzaghy-Azar M, Chitayat D, Sun L, Zaidi M, Wilson RC \& Yuen T. Genotypephenotype correlation in 1,507 families with congenital adrenal hyperplasia owing to 21-hydroxylase deficiency. PNAS 201312 2611-2616. (doi:10.1073/pnas.130005711)

3 Han TS, Walker BR, Arlt W \& Ross RJ. Treatment and health outcomes in adults with congenital adrenal hyperplasia. Nature Reviews Endocrinology 201410 115-124. (doi:10.1038/nrendo.2013.239)

4 Arlt W, Willis DS, Wild SH, Krone N, Doherty EJ, Hahner S, Han TS, Carroll PV, Conway GS, Rees DA et al. Health status of adults with congenital adrenal hyperplasia: a cohort study of 203 patients. Journal of Clinical Endocrinology and Metabolism 201095 5110-5121. (doi:10.1210/jc.2010-0917)

5 Bachelot A, Golmard JL, Dulon J, Dahmoune N, Leban M, Bouvattier C, Cabrol S, Leger J, Polak M \& Touraine P. Determining clinical and biological indicators for health outcomes in adult patients with childhood onset of congenital adrenal hyperplasia. European Journal of Endocrinology 2015173 175-184. (doi:10.1530/ EJE-14-0978)

6 Falhammar H, Frisén L, Hirschberg AL, Norrby C, Almqvist C, Nordenskjöld A \& Nordenström A. Increased cardiovascular and metabolic morbidity in patients with 21-hydroxylase deficiency: a Swedish population-based national cohort study. Journal of Clinical Endocrinology and Metabolism 2015100 3520-3528. (doi:10.1210/ JC.2015-2093)

7 Finkielstain GP, Kim MS, Sinaii N, Nishitani M, Van Ryzin C, Hill SC, Reynolds JC, Hanna RM \& Merke DP. Clinical characteristics of a cohort of 244 patients with congenital adrenal hyperplasia. Journal of Clinical Endocrinology and Metabolism 201297 4429-4438. (doi:10.1210/jc.2012-2102)

8 Falhammar H \& Thorén M. Clinical outcomes in the management of congenital adrenal hyperplasia. Endocrine 201241 355-373. (doi:10.1007/s12020-011-9591-x)

9 Falhammar H, Filipsson Nyström H, Wedell A \& Thorén M. Cardiovascular risk, metabolic profile, and body composition in adult males with congenital adrenal hyperplasia due to 21-hydroxylase deficiency. European Journal of Endocrinology 2011 164 285-293. (doi:10.1530/EJE-10-0877)

10 Bouvattier C, Esterle L, Renoult-Pierre $P$, de la Perrière AB, Illouz F, Kerlan V, Pascal-Vigneron V, Drui D, Christin-Maitre S, Galland F et al. Clinical outcome, hormonal status, gonadotrope axis, and testicular function in 219 adult men born with classic 21-hydroxylase deficiency. a French national survey. Journal of Clinical Endocrinology and Metabolism 2015100 2303-2313. (doi:10.1210/jc.2014-4124)

11 Kim MS, Ryabets-Lienhard A, Dao-Tran A, Mittelman SD, Gilsanz V, Schrager SM \& Geffner ME. Increased abdominal adiposity in adolescents and young adults with classical congenital adrenal hyperplasia due to 21-hydroxylase deficiency. Journal of Clinical Endocrinology and Metabolism 2015100 E1153-E1159 (doi:10.1210/ jc.2014-4033)

12 Moreira RPP, Villares SM, Madureira G, Mendonca BB \& Bachega TASS. Obesity and familial predisposition are significant determining factors of an adverse metabolic profile in young patients with congenital adrenal hyperplasia. Hormone Research in Poediatrics 201380 111-118. (doi:10.1159/000353762)

13 Mooij CF, Kroese JM, Claahsen-van der Grinten HL, Tack CJ \& Hermus AR. Unfavourable trends in cardiovascular and metabolic risk in paediatric and adult patients with congenital adrenal hyperplasia? Clinical Endocrinology 201073 137-146. (doi:10.1111/ j.1365-2265.2009.03690.x.)

14 Ubertini G, Bizzarri C, Grossi A, Gimigliano F, Ravà L, Fintini D \& Cappa M. Blood pressure and left ventricular characteristics in young patients with classical congenital adrenal hyperplasia due to 21-hydroxylase deficiency. International Journal of Pediatric Endocrinology 2009 383610. (doi:10.1155/2009/383610) 
15 Sartorato P, Zulian E, Benedini S, Mariniello B, Schiavi F, Bilora F, Pozzan G, Greggio N, Pagnan A, Mantero F et al. Cardiovascular risk factors and ultrasound evaluation of intimamedia thickness at common carotids, carotid bulbs, and femoral and abdominal aorta arteries in patients with classic congenital adrenal hyperplasia due to 21-hydroxylase deficiency. Journal of Clinical Endocrinology and Metabolism 200792 1015-1018. (doi:10.1210/jc.2006-1711)

16 Falhammar H, Filipsson H, Holmdahl G, Janson PO, Nordenskjöld A, Hagenfeldt $\mathrm{K} \&$ Thorén M. Metabolic profile and body composition in adult women with congenital adrenal hyperplasia due to 21-hydroxylase deficiency. Journal of Clinical Endocrinology and Metabolism 200792 110-116. (doi:10.1210/ jc.2006-1350)

17 Marra AM, Improda N, Capalbo D, Salzano A, Arcopinto M, De Paulis A, Alessio M, Lenzi A, Isidori AM, Cittadini A et al. Cardiovascular abnormalities and impaired exercise performance in adolescents with congenital adrenal hyperplasia. Journal of Clinical Endocrinology and Metabolism 2015100 644-652. (doi:10.1210/ jc.2014-1805)

18 Cutler GB \& Laue L. Congenital adrenal hyperplasia due to 21-hydroxylase deficiency. New England Journal of Medicine 199027 1806-1813. (doi:10.1056/NEJM199012273232605)

19 De Silva KSH, Kanumakala S, Brown JJ, Jones CL \& Warne GL. 24-hour ambulatory blood pressure profile in patients with congenital adrenal hyperplasia - a preliminary report. Journal of Pediatric Endocrinology and Metabolism 200417 1089-1095. (doi:10.1515/jpem.2004.17.8.1089)

20 Völkl TMK, Simm D, Dötsch J, Rascher W \& Dörr HG. Altered 24-hour blood pressure profiles in children and adolescents with classical congenital adrenal hyperplasia due to 21-hydroxylase deficiency. Journal of Clinical Endocrinology and Metabolism 200691 4888-4895. (doi:10.1210/jc.2006-1069)

21 Nermoen I, Brønstad I, Fougner KJ, Svartberg J, Øksnes M, Husebye ES \& Løvås K. Genetic, anthropometric and metabolic features of adult Norwegian patients with 21-hydroxylase deficiency. European Journal of Endocrinology 2012167 507-516. (doi:10.1530/ EJE-12-0196)

22 Mooij CF, Kroese JM, Sweep FCGJ, Hermus AR \& Tack CJ. Adult patients with congenital adrenal hyperplasia have elevated blood pressure but otherwise a normal cardiovascular risk profile. PLoS ONE 20116 e24204. (doi:10.1371/journal.pone.0024204)

23 Roche EF, Charmandari E, Dattani MT \& Hindmarsh PC. Blood pressure in children and adolescents with congenital adrenal hyperplasia (21-hydroxylase deficiency): a preliminary report. Clinical Endocrinology 200358 589-596. (doi:10.1046/j.13652265.2003.01757.x)

24 Subbarayan A, Dattani MT, Peters CJ \& Hindmarsh PC. Cardiovascular risk factors in children and adolescents with congenital adrenal hyperplasia due to 21-hydroxylase deficiency. Clinical Endocrinology 201480 471-477. (doi:10.1111/cen.12265)

25 Stein JH, Korcarz CE, Hurst RT, Lonn E, Kendall CB, Mohler ER, Najjar SS, Rembold CM, Post WS \& American Society of Echocardiography Carotid Intima-Media Thickness Task Force. Use of carotid ultrasound to identify subclinical vascular disease and evaluate cardiovascular disease risk: a consensus statement from the American Society of Echocardiography Carotid Intima-Media Thickness Task Force. Endorsed by the Society for Vascular Medicine. Journal of the American Society of echocardiography 200821 93-111 (doi:10.1016/j.echo.2007.11.011.)

26 Harrington J, Peña AS, Gent R, Hirte C \& Couper J. Adolescents with congenital adrenal hyperplasia because of 21-hydroxylase deficiency have vascular dysfunction. Clinical Endocrinology 201276 837-842. (doi:10.1111/j.1365-2265.2011.04309.x.)

27 Amr NH, Ahmed AY \& Ibrahim YA. Carotid intima media thickness and other cardiovascular risk factors in children with congenital adrenal hyperplasia. Journal of Endocrinological Investigation 201437 1001-1008. (doi:10.1007/s40618-014-0148-8.)
28 Kim MS, Dao-Tran A, Davidowitz E, Tseng T, Gilsanz V, Ryabets-Lienhard A, Nguyen E \& Geffner ME. Carotid intima-media thickness is associated with increased androgens in adolescents and young adults with classical congenital adrenal hyperplasia. Hormone Research in Poediatrics 201685 242-249. (doi:10.1159/000444169)

29 Wasniewska M, Balsamo A, Valenzise M, Manganaro A, Faggioli G, Bombaci S, Conti V, Ferri M, Aversa T, Cicognani A et al. Increased large artery intima media thickness in adolescents with either classical or non-classical congenital adrenal hyperplasia. Journal of Endocrinological Investigation 201336 12-15. (doi:10.3275/8194)

30 Abehsira G, Bachelot A, Badilini F, Koehl L, Lebot M, Favet C, Touraine P, Funck-Brentano C \& Salem JE. Complex influence of gonadotropins and sex steroid hormones on QT interval duration. Journal of Clinical Endocrinology and Metabolism 2016101 2776-2784. (doi:10.1210/jc.2016-1877)

31 Falhammar H, Frisén L, Norrby C, Hirschberg AL, Almqvist C, Nordenskjöld A \& Nordenström A. Increased mortality in patients with congenital adrenal hyperplasia due to 21-hydroxylase deficiency. Journal of Clinical Endocrinology and Metabolism 201499 2715-2721. (doi:10.1210/jc.2014-2957)

32 Moreira RP, Gomes LG, Mendonca BB \& Bachega TA. Impact of glucocorticoid receptor gene polymorphisms on the metabolic profile of adult patients with the classical form of 21-hydroxylase deficiency. PLos ONE 20127 e44893. (doi:10.1371/journal. pone.0044893)

33 Gastaud F, Bouvattier C, Duranteau L, Brauner R, Thibaud E, Kutten $\mathrm{F} \&$ Bougnères $\mathrm{P}$. Impaired sexual and reproductive outcomes in women with classical forms of congenital adrenal hyperplasia. Journal of Clinical Endocrinology and Metabolism 200792 1391-1396. (doi:10.1210/jc.2006-1757)

34 Merke DP \& Bornstein SR. Congenital adrenal hyperplasia. Lancet 200518 2125-2136. (doi:10.1016/S0140-6736(05)66736-0)

35 Bachelot A, Chakhtoura Z, Plu-Bureau G, Coudert M, Coussieu C, Badachi Y, Dulon J, Charbit B, Touraine P \& CAHLH study group. Influence of hormonal control on LH pulsatility and secretion in women with classical congenital adrenal hyperplasia. European Journal of Endocrinology 2012167 499-505. (doi:10.1530/EJE-12-0454)

36 Wang LC \& Poppas DP. Surgical outcomes and complications of reconstructive surgery in the female congenital adrenal hyperplasia patient: What every endocrinologist should know. Journal of Steroid Biochemistry and Molecular Biology 2017165 137-144. (doi:10.1016/j. jsbmb.2016.03.021)

37 Sturm RM, Durbin-Johnson B \& Kurzrock EA. Congenital adrenal hyperplasia: current surgical management at academic medical centers in the United States. Journal of Urology 2015193 1796-1801. (doi:10.1016/j.juro.2014.11.008)

38 Ogilvie CM, Crouch NS, Rumsby G, Creighton SM, Liao L-M \& Conway GS. Congenital adrenal hyperplasia in adults: a review of medical, surgical and psychological issues. Clinical Endocrinology 200664 2-11. (doi:10.1111/j.1365-2265.2005.02410.x)

39 Reifsnyder JE, Stites J, Bernabé KJ, Galan D, Felsen D \& Poppas DP. Nerve sparing clitoroplasty is an option for adolescent and adult female patients with congenital adrenal hyperplasia and clitoral pain following prior clitoral recession or incomplete reduction. Journal of Urology 2016195 1270-1273. (doi:10.1016/j. juro.2015.12.053.)

40 Lesma A, Bocciardi A, Montorsi F \& Rigatti P. Passerini-glazel feminizing genitoplasty: modifications in 17 years of experience with 82 cases. European Urology 200752 1638-1644. (doi:10.1016/j. eururo.2007.02.068)

41 Mouriquand PD, Gorduza DB, Gay C-L, Meyer-Bahlburg HFL, Baker L, Baskin LS, Bouvattier C, Braga LH, Caldamone AC, Duranteau L et al. Surger in disorders of sex development (DSD) with a gender isssue: if (why), when, and how? Journal of Pediatric Urology 201612 139-149. (doi:10.1016/j.jpurol.2016.04.001) 
42 Hagenfeldt K, Janson PO, Holmdahl G, Falhammar H, Filipsson H, Frisén L, Thorén $\mathrm{M} \&$ Nordenskjöld A. Fertility and pregnancy outcome in women with congenital adrenal hyperplasia due to 21-hydroxylase deficiency. Human Reproduction 200823 1607-1613. (doi:10.1093/humrep/den118)

43 Casteràs A, De Silva P, Rumsby G \& Conway GS. Reassessing fecundity in women with classical congenital adrenal hyperplasia (CAH): normal pregnancy rate but reduced fertility rate. Clinical Endocrinology 200970 833-837. (doi:10.1111/j.13652265.2009.03563.x)

44 Strandqvist A, Falhammar H, Lichtenstein P, Hirschberg AL, Wedell A, Norrby C, Nordenskjöld A, Frisén L \& Nordenström A. Suboptimal psychosocial outcomes in patients with congenital adrenal hyperplasia: epidemiological studies in a nonbiased national cohort in Sweden. Journal of Clinical Endocrinology and Metabolism 201499 1425-1432. (doi:10.1210/jc.2013-3326)

45 Reisch N, Scherr M, Flade L, Bidlingmaier M, Schwarz H-P, Müller-Lisse U, Reincke M, Quinkler M \& Beuschlein F. Total adrenal volume but not testicular adrenal rest tumor volume is associated with hormonal control in patients with 21-hydroxylase deficiency. Journal of Clinical Endocrinology and Metabolism 201095 2065-2072. (doi:10.1210/jc.2009-1929)

46 Pierre P, Despert F, Tranquart F, Coutant R, Tardy V, Kerlan V, Sonnet E, Baron S, Lorcy Y, Emy P et al. Adrenal rest tissue in gonads of patients with classical congenital adrenal hyperplasia: multicenter study of 45 French male patients. Annales d'Endocrinologie 201273 515-522. (doi:10.1016/j.ando.2012.09.005)

47 Claahsen-van der Grinten HL, Dehzad F, Kamphuis-van Ulzen K \& de Korte CL. Increased prevalence of testicular adrenal rest tumours during adolescence in congenital adrenal hyperplasia. Hormone Research in Poediatrics 201482 238-244. (doi:10.1159/000365570)

48 Aycan Z, Bas VN, Cetinkaya S, Yilmaz Agladioglu S \& Tiryaki T. Prevalence and long-term follow-up outcomes of testicular adrenal rest tumours in children and adolescent males with congenital adrenal hyperplasia. Clinical Endocrinology 201378 667-672. (doi:10.1111/cen.12033.)

49 Reisch N, Flade L, Scherr M, Rottenkolber M, Pedrosa Gil F, Bidlingmaier M, Wolff H, Schwarz HP, Quinkler M, Beuschlein F et al. High prevalence of reduced fecundity in men with congenital adrenal hyperplasia. Journal of Clinical Endocrinology and Metabolism 200994 1665-1670. (doi:10.1210/jc.2008-1414)

50 Yu MK, Jung MK, Kim KE, Kwon AR, Chae HW, Kim DH \& Kim HS. Clinical manifestations of testicular adrenal rest tumor in males with congenital adrenal hyperplasia. Annals of Pediatric and Endocrinology Metabolism 201520 155-161. (doi:10.6065/ apem.2015.20.3.155.)

51 Chihaoui M, Kanoun F, Chaker F, Yazidi M, Bouchrit K, Mizouni H, Feki M, Kharrat M \& Slimane H. Testicular adrenal rest tumours in young adult males with congenital adrenal hyperplasia: prevalence and impact on testicular function. Andrologia 201648 45-50. (doi:10.1111/and.12416)

52 Reisch N, Rottenkolber M, Greifenstein A, Krone N, Schmidt H, Reincke M, Schwarz HP \& Beuschlein F. Testicular adrenal rest tumors develop independently of long-term disease control: a longitudinal analysis of 50 adult men with congenital adrenal hyperplasia due to classic 21-hydroxylase deficiency. Journal of Clinical Endocrinology and Metabolism 201398 E1820-E1826. (doi:10.1210/jc.2012-3181)

53 Smeets EEJW, Span PN, van Herwaarden AE, Wevers RA, Hermus ARMM, Sweep FC \& Claahsen-van der Grinten HL. Molecular characterization of testicular adrenal rest tumors in congenital adrenal hyperplasia: lesions with both adrenocortical and Leydig cell features. Journal of Clinical Endocrinology and Metabolism 2015100 E524-E530. (doi:10.1210/jc.2014-2036)

54 Bry-Gauillard H, Cartes A \& Young J. Mitotane for 21-hydroxylase deficiency in an infertile man. New England Journal of Medicine 2014 20 2042-2044. (doi:10.1056/NEJMc1410041)
55 King TFJ, Lee MC, Williamson EEJ \& Conway GS. Experience in optimizing fertility outcomes in men with congenital adrenal hyperplasia due to 21 hydroxylase deficiency. Clinical Endocrinology 201684 830-836. (doi:10.1111/cen.13001)

56 Rohayem J, Tüttelmann F, Mallidis C, Nieschlag E, Kliesch S \& Zitzmann M. Restoration of fertility by gonadotropin replacement in a man with hypogonadotropic azoospermia and testicular adrenal rest tumors due to untreated simple virilizing congenital adrenal hyperplasia. European Journal of Endocrinology 2014170 K11-K17. (doi:10.1530/EJE-13-0449)

57 Falhammar H, Nyström HF, Ekström U, Granberg S, Wedell A \& Thorén M. Fertility, sexuality and testicular adrenal rest tumors in adult males with congenital adrenal hyperplasia. European Journal of Endocrinology 2012166 441-449. (doi:10.1530/EJE-11-0828)

58 Falhammar H, Nyström HF \& Thorén M. Quality of life, social situation, and sexual satisfaction, in adult males with congenital adrenal hyperplasia. Endocrine 201447 299-307. (doi:10.1007/ s12020-013-0161-2)

59 Dudzińska B, Leubner J, Ventz M \& Quinkler M. Sexual wellbeing in adult male patients with congenital adrenal hyperplasia. International Journal of Endocrinology 20142014469289. (doi:10.1155/2014/469289)

60 Reisch N. Substitution therapy in adult patients with congenital adrenal hyperplasia. Best Practice and Research. Clinical Endocrinology and Metabolism 201529 33-45. (doi:10.1016/j.beem.2014.11.002)

61 Turcu AF \& Auchus RJ. Novel treatment strategies in congenital adrenal hyperplasia. Current Opinion in Endocrinology, Diabetes, and Obesity 201623 225-232. (doi:10.1097/MED.0000000000000256)

62 Johannsson G, Bergthorsdottir R, Nilsson AG, Lennernas H, Hedner T \& Skrtic S. Improving glucocorticoid replacement therapy using a novel modified-release hydrocortisone tablet: a pharmacokinetic study. European Journal of Endocrinology 2009161 119-130. (doi:10.1530/EJE-09-0170)

63 Johannsson G, Nilsson AG, Bergthorsdottir R, Burman P, Dahlqvist P, Ekman B, Engström BE, Olsson T, Ragnarsson O, Ryberg M et al. Improved cortisol exposure-time profile and outcome in patients with adrenal insufficiency: a prospective randomized trial of a novel hydrocortisone dual-release formulation. Journal of Clinical Endocrinology and Metabolism 201297 473-481. (doi:10.1210/ jc.2011-1926)

64 Quinkler M, Miodini Nilsen R, Zopf K, Ventz M \& Øksnes M. Modified-release hydrocortisone decreases BMI and HbA1c in patients with primary and secondary adrenal insufficiency. European Journal of Endocrinology 2015172 619-626. (doi:10.1530/ EJE-14-1114)

65 Debono M, Mallappa A, Gounden V, Nella AA, Harrison RF, Crutchfield CA, Backlund PS, Soldin SJ, Ross RJ \& Merke DP. Hormonal circadian rhythms in patients with congenital adrenal hyperplasia: identifying optimal monitoring times and novel disease biomarkers. European Journal of Endocrinology 2015173 727-737. (doi:10.1530/EJE-15-0064)

66 Verma S, Vanryzin C, Sinaii N, Kim MS, Nieman LK, Ravindran S, Calis KA, Arlt W, Ross RJ \& Merke DP. A pharmacokinetic and pharmacodynamic study of delayed- and extended-release hydrocortisone (Chronocort) vs. conventional hydrocortisone (Cortef) in the treatment of congenital adrenal hyperplasia. Clinical Endocrinology 201072 441-447. (doi:10.1111/j.13652265.2009.03636.x)

67 Mallappa A, Sinaii N, Kumar P, Whitaker MJ, Daley L-A, Digweed D, Eckland DJ, Van Ryzin C, Nieman LK, Arlt W et al. A phase 2 study of Chronocort, a modified-release formulation of hydrocortisone, in the treatment of adults with classic congenital adrenal hyperplasia. Journal of Clinical Endocrinology and Metabolism $20151001137-1145$. (doi:10.1210/jc.2014-3809)

68 Merza Z, Rostami-Hodjegan A, Memmott A, Doane A, Ibbotson V, Newell-Price J, Tucker GT \& Ross RJ. Circadian hydrocortisone 
infusions in patients with adrenal insufficiency and congenital adrenal hyperplasia. Clinical Endocrinology 200665 45-50. (doi:10.1111/j.1365-2265.2006.02544.x)

69 Oksnes M, Björnsdottir S, Isaksson M, Methlie P, Carlsen S, Nilsen RM, Broman JE, Triebner K, Kämpe O, Hulting AL et al. Continuous subcutaneous hydrocortisone infusion versus oral hydrocortisone replacement for treatment of addison's disease: a randomized clinical trial. Journal of Clinical Endocrinology and Metabolism 201499 1665-1674. (doi:10.1210/jc.2013-4253)

70 Gagliardi L, Nenke MA, Thynne TRJ, von der Borch J, Rankin WA, Henley DE, Sorbello J, Inder WJ \& Torpy DJ. Continuous subcutaneous hydrocortisone infusion therapy in Addison's disease: a randomized, placebo-controlled clinical trial. Journal of Clinical Endocrinology and Metabolism 201499 4149-4157. (doi:10.1210/jc.2014-2433)

71 Russell GM, Durant C, Ataya A, Papastathi C, Bhake R, Woltersdorf W \& Lightman S. Subcutaneous pulsatile glucocorticoid replacement therapy. Clinical Endocrinology 201481 289-293. (doi:10.1111/cen.12470)

72 Nella AA, Mallappa A, Perritt AF, Gounden V, Kumar P, Sinaii A, Daley LA, Ling A, Liu CY, Soldin SJ et al. A phase 2 study of continuous subcutaneous hydrocortisone infusion in adults with congenital adrenal hyperplasia. Journal of Clinical Endocrinology and Metabolism 2016101 4690-4698. (doi 10.1210/jc.2016-1916)

73 Tiosano D, Vlodavsky E, Filmar S, Weiner Z, Goldsher D \& Bar-Shalom R. Ovarian adrenal rest tumor in a congenital adrenal hyperplasia patient with adrenocorticotropin hypersecretion following adrenalectomy. Hormone Research in Poediatrics 201074 223-228. (doi:10.1159/000295722)

74 Crocker MK, Barak S, Millo CM, Beall SA, Niyyati M, Chang R, Avila NA, Van Ryzin C, Segars J, Quezado M et al. Use of PET/CT with cosyntropin stimulation to identify and localize adrenal rest tissue following adrenalectomy in a woman with congenital adrenal hyperplasia. Journal of Clinical Endocrinology and Metabolism 201297 E2084-E2089. (doi:10.1210/jc.2012-2298)

75 Gentilin E, Molè D, Gagliano T, Minoia M, Ambrosio MR, Degli Uberti EC \& Zatelli MC. Inhibitory effects of mitotane on viability and secretory activity in mouse gonadotroph cell lines. Reproductive Toxicology 201445 71-76. (doi:10.1016/j. reprotox.2014.01.008)

76 Hescot S, Slama A, Lombès A, Paci A, Remy H, Leboulleux S, Chadarevian R, Trabado S, Amazit L, Young J et al. Mitotane alters mitochondrial respiratory chain activity by inducing cytochrome c oxidase defect in human adrenocortical cells. Endocrine-Related Cancer 201320 371-381. (doi:10.1530/ERC-12-0368)

77 Ryan CJ, Smith MR, Fizazi K, Saad F, Mulders PFA, Sternberg CN, Miller K, Logothetis CJ, Shore ND, Small EJ et al. Abiraterone acetate plus prednisone versus placebo plus prednisone in chemotherapynaive men with metastatic castration-resistant prostate cancer (COU-AA-302): final overall survival analysis of a randomised, double-blind, placebo-controlled phase 3 study. Lancet Oncology 201516 152-160. (doi:10.1016/S1470-2045(14)71205-7

78 Auchus RJ, Buschur EO, Chang AY, Hammer GD, Ramm C, Madrigal D, Wang G, Gonzalez M, Xu XS, Smit JW et al. Abiraterone acetate to lower androgens in women with classic 21-hydroxylase deficiency. Journal of Clinical Endocrinology and Metabolism 201499 2763-2770. (doi:10.1210/jc.2014-1258)

79 Clark AJ, Forfar R, Hussain M, Jerman J, McIver E, Taylor D \& Chan L. ACTH antagonists. Frontiers in Endocrinology 20167101. (doi:10.3389/fendo.2016.00101)

80 Turcu AF, Spencer-Segal JL, Farber RH, Luo R, Grigoriadis DE, Ramm CA, Madrigal D, Muth T, O'Brien CF \& Auchus RJ. Singledose study of a corticotropin-releasing factor receptor-1 antagonist in women with 21-hydroxylase deficiency. Journal of Clinical Endocrinology and Metabolism 2016101 1174-1180. (doi:10.1210/ jc.2015-3574)
81 David M \& Forest MG. Prenatal treatment of congenital adrenal hyperplasia resulting from 21-hydroxylase deficiency. Journal of Pediatrics 1984105 799-803. (doi:10.1016/S0022-3476(84)80310-8)

82 Evans MI, Chrousos GP, Mann DW, Larsen JW, Green I, McCluskey J, Loriaux DL, Fletcher JC, Koons G \& Overpeck J. Pharmacologic suppression of the fetal adrenal gland in utero. Attempted prevention of abnormal external genital masculinization in suspected congenital adrenal hyperplasia. JAMA 198515 1015-1020. (doi:10.1001/jama.1985.03350310097034)

83 Forest MG, Morel Y \& David M. Prenatal treatment of congenital adrenal hyperplasia. Trends in Endocrinology and Metabolism 19989 284-289. (doi:10.1016/S1043-2760(98)00067-8)

84 New MI, Carlson A, Obeid J, Marshall I, Cabrera MS, Goseco A, Lin-Su K, Putnam AS, Wei JQ \& Wilson RC. Prenatal diagnosis for congenital adrenal hyperplasia in 532 pregnancies. Journal of Clinical Endocrinology and Metabolism 200186 5651-5657. (doi:10.1210/ jcem.86.12.8072)

85 Linder BL, Esteban NV, Yergey AL, Winterer JC, Loriaux DL \& Cassorla F. Cortisol production rate in childhood and adolescence. Journal of Pediatrics 1990117 892-896. (doi:10.1016/S0022-3476(05)80128-3)

86 Esteban NV, Loughlin T, Yergey AL, Zawadzki JK, Booth JD, Winterer JC \& Loriaux DL. Daily cortisol production rate in man determined by stable isotope dilution/mass spectrometry. Journal of Clinical Endocrinology and Metabolism 199172 39-45. (doi:10.1210/ jcem-72-1-39)

87 Partsch CJ, Sippell WG, MacKenzie IZ \& Aynsley-Green A. The steroid hormonal milieu of the undisturbed human fetus and mother at 16-20 weeks gestation. Journal of Clinical Endocrinology and Metabolism 199173 969-974. (doi:10.1210/jcem-73-5-969)

88 Kari MA, Raivio KO, Stenman UH \& Voutilainen R. Serum cortisol, dehydroepiandrosterone sulfate, and steroid-binding globulins in preterm neonates: effect of gestational age and dexamethasone therapy. Pediatric Research 199640 319-324. (doi:10.1203/00006450199608000-00021)

89 Coleman MA \& Honour JW. Reduced maternal dexamethasone dosage for the prenatal treatment of congenital adrenal hyperplasia. BJOG 2004111 176-178. (doi:10.1046/j.1471-0528.2003.00040.x)

90 Tardy-Guidollet V, Menassa R, Costa J-M, David M, BouvattierMorel C, Baumann C, Houang M, Lorenzini F, Philip N, Odent $\mathrm{S}$ et al. New management strategy of pregnancies at risk of congenital adrenal hyperplasia using fetal sex determination in maternal serum: French cohort of 258 cases (2002-2011). Journal of Clinical Endocrinology and Metabolism 201499 1180-1188. (doi:10.1210/jc.2013-2895)

91 Forest MG, Bétuel H \& David M. Prenatal treatment in congenital adrenal hyperplasia due to 21-hydroxylase deficiency: up-date 88 of the French multicentric study. Endocrine Research 198915 277-301. (doi:10.1080/07435808909039101)

92 Dörr HG \& Sippell WG. Prenatal dexamethasone treatment in pregnancies at risk for congenital adrenal hyperplasia due to 21-hydroxylase deficiency: effect on midgestational amniotic fluid steroid levels. Journal of Clinical Endocrinology and Metabolism 1993 76 117-120. (doi:10.1210/jcem.76.1.8421074)

93 Forest MG, David M \& Morel Y. Prenatal diagnosis and treatment of 21-hydroxylase deficiency. Journal of Steroid Biochemistry and Molecular Biology 199345 75-82. (doi:10.1016/0960-0760(93)90125-G)

94 Mercado AB, Wilson RC, Cheng KC, Wei JQ \& New MI. Prenatal treatment and diagnosis of congenital adrenal hyperplasia owing to steroid 21-hydroxylase deficiency. Journal of Clinical Endocrinology and Metabolism 199580 2014-2020. (doi:10.1210/ jcem.80.7.7608248)

95 Lajic S, Wedell A, Bui TH, Ritzén EM \& Holst M. Long-term somatic follow-up of prenatally treated children with congenital adrenal hyperplasia. Journal of Clinical Endocrinology and Metabolism $1998 \mathbf{8 3}$ 3872-3880. (doi:10.1210/jcem.83.11.5233) 
96 Forest MG \& Dörr HG. Prenatal therapy in congenital adrenal hyperplasia due to 21-hydroxylase deficiency: retrospective follow-up study of 253 treated pregnancies in 215 families. Endocrinologist 200313 252-259. (doi:10.1097/01. ten.0000081690.21823.af)

97 Gorduza D, Vidal I, Birraux J, Gay C-L, Demède D, Mure P-Y $\&$ Mouriquand P. The surgical challenges of disorders of sex development (DSD). Archivos Espanoles de Urologia 201063 495-504.

98 Mercè Fernández-Balsells M, Muthusamy K, Smushkin G, Lampropulos JF, Elamin MB, Abu Elnour NO, Elamin KB, Agrwal N, Gallegos-Orozco JF, Lane MA et al. Prenatal dexamethasone use for the prevention of virilization in pregnancies at risk for classical congenital adrenal hyperplasia because of 21-hydroxylase (CYP21A2) deficiency: a systematic review and meta-analyses. Clinical Endocrinology 201073 436-444. (doi:10.1111/j.13652265.2010.03826.x)

99 Gorduza D, Tardy-Guidollet V, Robert E, Gay C-L, Chatelain P, David M, Bretones P, Lienhardt-Roussie A, Brac de la Perriere A, Morel $Y$ et al. Late prenatal dexamethasone and phenotype variations in 46,XX CAH: concerns about current protocols and benefits for surgical procedures. Journal of Pediatric Urology 201410 941-947. (doi:10.1016/j.jpurol.2014.02.003)

100 Wilson JD, Rivarola MA, Mendonca BB, Warne GL, Josso N, Drop SLS \& Grumbach MM. Advice on the management of ambiguous genitalia to a young endocrinologist from experienced clinicians. Seminars in Reproductive Medicine 201230 339-350. (doi:10.1055/s-0032-1324717)

101 Kulshreshtha B, Khadgawat R, Eunice M \& Ammini AC. Congenital adrenal hyperplasia: Results of medical therapy on appearance of external genitalia. Journal of Pediatric Urology 20106 555-559. (doi:10.1016/j.jpurol.2010.01.001)

102 Lo YM, Corbetta N, Chamberlain PF, Rai V, Sargent IL, Redman CW $\&$ Wainscoat JS. Presence of fetal DNA in maternal plasma and serum. Lancet 199716 485-487. (doi:10.1016/S01406736(97)02174-0)

103 Costa JM, Benachi A, Gautier E, Jouannic JM, Ernault P \& Dumez Y. First-trimester fetal sex determination in maternal serum using real-time PCR. Prenatal Diagnosis. 200121 1070-1074. (doi:10.1002/pd.219)

104 Bartha JL, Finning K \& Soothill PW. Fetal sex determination from maternal blood at 6 weeks of gestation when at risk for 21-hydroxylase deficiency. Obstetrics and Gynecoly 2003101 1135-1136. (doi :10.1097/00006250-200305001-00032)

105 Bolnick AD, Fritz R, Jain C, Kadam L, Bolnick JM, Kilburn BA, Singh M, Diamond MP, Drewlo S \& Armant DR. Trophoblast retrieval and isolation from the cervix for noninvasive, first trimester, fetal gender determination in a carrier of congenital adrenal hyperplasia. Reproductive Sciences 201623 717-722. (doi:10.1177/1933719116632922)

106 New MI, Tong YK, Yuen T, Jiang P, Pina C, Chan KCA, Khattab A, Liao GJ, Yau M, Kim SM et al. Noninvasive prenatal diagnosis of congenital adrenal hyperplasia using cell-free fetal DNA in maternal plasma. Journal of Clinical Endocrinology and Metabolism 201499 E1022-E1030. (doi:10.1210/jc.2014-1118)

107 Khattab A, Yuen T, Sun L, Yau M, Barhan A, Zaidi M, Lo YM $\&$ New MI. Noninvasive prenatal diagnosis of congenital adrenal hyperplasia. Endocrine Development 201630 37-41. (doi:10.1159/000439326)

108 Lajic S, Nordenström A, Ritzén EM \& Wedell A. Prenatal treatment of congenital adrenal hyperplasia. European Journal of Endocrinology 2004151 U63-U69. (doi:10.1530/eje.0.151U063)

109 Nimkarn S \& New MI. Prenatal diagnosis and treatment of congenital adrenal hyperplasia. Hormone Research 200767 53-60. (doi:10.1159/000096353)
110 Ali H, Kalashnikova I, White MA, Sherman M \& Rytting E. Preparation, characterization, and transport of dexamethasoneloaded polymeric nanoparticles across a human placental in vitro model. International Journal of Pharmaceutics 201315 149-157. (doi:10.1016/j.ijpharm.2013.07.010)

111 Seckl JR. Prenatal glucocorticoids and long-term programming. European Journal of Endocrinology 2004151 U49-U62. (doi:10.1530/ eje.0.151U049)

112 Yeh TF, Lin YJ, Lin HC, Huang CC, Hsieh WS, Lin CH \& Tsai CH. Outcomes at school age after postnatal dexamethasone therapy for lung disease of prematurity. New England Journal of Medicine 200425 1304-1313. (doi:10.1056/NEJMoa032089)

113 Uno H, Lohmiller L, Thieme C, Kemnitz JW, Engle MJ, Roecker EB \& Farrell PM. Brain damage induced by prenatal exposure to dexamethasone in fetal rhesus macaques. I. Hippocampus. Brain Research. Development Brain Research 19901 157-167. (doi:10.1016/0165-3806(90)90002-G)

114 Miller WL. Dexamethasone treatment of congenital adrenal hyperplasia in utero: an experimental therapy of unproven safety. Journal of Urology 1999162 537-540. (doi:10.1016/S00225347(05)68624-7)

115 Trautman PD, Meyer-Bahlburg HF, Postelnek J \& New MI. Effects of early prenatal dexamethasone on the cognitive and behavioral development of young children: results of a pilot study. Psychoneuroendocrinology 199520 439-449. (doi:10.1016/03064530(94)00070-0)

116 Meyer-Bahlburg HFL, Dolezal C, Baker SW, Carlson AD, Obeid JS $\&$ New MI. Cognitive and motor development of children with and without congenital adrenal hyperplasia after early-prenatal dexamethasone. Journal of Clinical Endocrinology and Metabolism 2004 89 610-614. (doi:10.1210/jc.2002-021129)

117 Meyer-Bahlburg HFL, Dolezal C, Haggerty R, Silverman M \& New MI. Cognitive outcome of offspring from dexamethasonetreated pregnancies at risk for congenital adrenal hyperplasia due to 21-hydroxylase deficiency. European Journal of Endocrinology 2012167 103-110. (doi:10.1530/EJE-11-0789)

118 Hirvikoski T, Nordenström A, Lindholm T, Lindblad F, Ritzén EM, Wedell A \& Lajic S. Cognitive functions in children at risk for congenital adrenal hyperplasia treated prenatally with dexamethasone. Journal of Clinical Endocrinology and Metabolism 2007 92 542548. (doi:10.1210/jc.2006-1340)

119 Hirvikoski T, Nordenström A, Lindholm T, Lindblad F, Ritzén EM \& Lajic S. Long-term follow-up of prenatally treated children at risk for congenital adrenal hyperplasia: does dexamethasone cause behavioural problems? European Journal of Endocrinology 2008159 309-316. (doi:10.1530/EJE-08-0280)

120 Hirvikoski T, Lindholm T, Lajic S \& Nordenström A. Gender role behaviour in prenatally dexamethasone-treated children at risk for congenital adrenal hyperplasia--a pilot study. Acta Paediatrica 1992. 2011100 112-119. (doi:10.1111/j.1651-2227.2011.02260.x)

121 Wallensteen L, Zimmermann M, Sandberg MT, Gezelius A, Nordenström A, Hirvikoski T \& Lajic S. Evaluation of behavioral problems after prenatal dexamethasone treatment in Swedish adolescents at risk of CAH. Hormones and Behavior 201685 5-11. (doi:10.1016/j.yhbeh.2016.06.011)

122 Clayton PE, Miller WL, Oberfield SE, Ritzén EM, Sippell WG, Speiser PW \& ESPE/ LWPES CAH Working Group. Consensus statement on 21-hydroxylase deficiency from the European Society for Paediatric Endocrinology and the Lawson Wilkins Pediatric Endocrine Society. Hormone Research 200258 188-195. (doi:10.1159/000065490)

123 Joint LWPES/ESPE CAH Working Group. Consensus statement on 21-hydroxylase deficiency from the Lawson Wilkins Pediatric Endocrine Society and the European Society for Paediatric 
Endocrinology. Journal of Clinical Endocrinology and Metabolism 2002 87 4048-4053. (doi:10.1210/jc.2002-020611)

124 Forest MG. Recent advances in the diagnosis and management of congenital adrenal hyperplasia due to 21-hydroxylase deficiency. Human Reproduction Update 200410 469-485. (doi:10.1093/humupd/ dmh047)

125 Speiser PW, Azziz R, Baskin LS, Ghizzoni L, Hensle TW, Merke DP, Meyer-Bahlburg HF, Miller WL, Montori VM, Oberfield SE et al. Congenital adrenal hyperplasia due to steroid 21-hydroxylase deficiency: an Endocrine Society clinical practice guideline. Journal of Clinical Endocrinology and Metabolism 201095 4133-4160. (doi:10.1210/jc.2009-2631)
126 Miller WL \& Witchel SF. Prenatal treatment of congenital adrenal hyperplasia: risks outweigh benefits. American Journal of Obstetrics and Gynecology 2013208 354-359. (doi:10.1016/j.ajog.2012.10.885)

127 Miller WL. Fetal endocrine therapy for congenital adrenal hyperplasia should not be done. Best Practice and Research. Clinical Endocrinology and Metabolism 201529 469-483. (doi:10.1016/ j.beem.2015.01.005)

128 Hirvikoski T, Nordenström A, Wedell A, Ritzén M \& Lajic S. Prenatal dexamethasone treatment of children at risk for congenital adrenal hyperplasia: the Swedish experience and standpoint. Journal of Clinical Endocrinology and Metabolism 201297 1881-1883. (doi:10.1210/jc.2012-1222)

Received 26 October 2016

Revised version received 3 January 2017

Accepted 20 January 2017 